\title{
Incidental diagnosis of granulosa cell tumour in a 25-year-old woman
}

\section{P. G. Paul*, Sanghamitra Thakur, Anjana Annal, George Paul, K. Anusha Chowdary}

Paul's hospital, Centre for Advanced Endoscopy and Infertility Treatment, Kochi, Kerala, India

Received: 22 December 2020

Accepted: 01 February 2021

\section{*Correspondence:}

Dr. P. G. Paul,

E-mail: drpaulpg@gmail.com

Copyright: () the author(s), publisher and licensee Medip Academy. This is an open-access article distributed under the terms of the Creative Commons Attribution Non-Commercial License, which permits unrestricted non-commercial use, distribution, and reproduction in any medium, provided the original work is properly cited.

\section{ABSTRACT}

A 25-year-old woman presented with backache of 2 weeks duration and had 45-60 days menstrual cycle. On transvaginal sonography (TVS), her left adnexa showed a heterogenous solid mass of $5.3 \times 4.2 \mathrm{~cm}$ and moderate vascularity on color doppler. Serum inhibin B was raised to $2249 \mathrm{pg} / \mathrm{ml}$. MRI showed $5.5 \times 4.5 \mathrm{~cm}$ solid mass in the left ovary with lobulated margins suggestive of sex cord-stromal/ germ cell tumor. Laparoscopy showed an enlarged left ovary with intact surface. Left adnexectomy with staging biopsies and infracolic omentectomy was performed. Histopathology showed adult granulosa cell tumor with intact ovarian capsule. One-month post-surgery, inhibin B level was $44 \mathrm{pg} / \mathrm{ml}$. She wishes to conceive after six months follow-up.

Keywords: Granulosa cell tumour, Inhibin B, Laparoscopy

\section{INTRODUCTION}

Solid ovarian tumours constitute a small percentage of ovarian tumours, that too less common in young women. ${ }^{1}$ The commonest ovarian tumor in younger women is dysgerminoma. Diagnosis of solid tumor in young women are often delayed because they mimic common conditions like pedunculated fibroids, fibromas, thecomas, polycystic ovary, malignant ovarian tumors, or an ovarian torsion. We present a case of Granulosa cell tumor (GCT) in a young married woman with irregular cycles.

\section{CASE REPORT}

A 25-year-old woman presented with backache of 2 weeks duration. She was married for two years and does not wish to conceive at present. She had 45-60 days menstrual cycle with a flow of 5-7 days. On transvaginal sonography (TVS), her left adnexa showed a heterogenous solid mass of $5.3 \times 4.2 \mathrm{~cm}$ and moderate vascularity on color doppler, ovary was not seen separately (Figure 1). The uterus was normal size and endometrial thickness was $7 \mathrm{~mm}$, right ovary showed polycystic morphology. MRI showed
$5.5 \times 4.5 \mathrm{~cm}$ solid mass in the left ovary with lobulated margins suggestive of sex cord-stromal/ germ cell tumour.

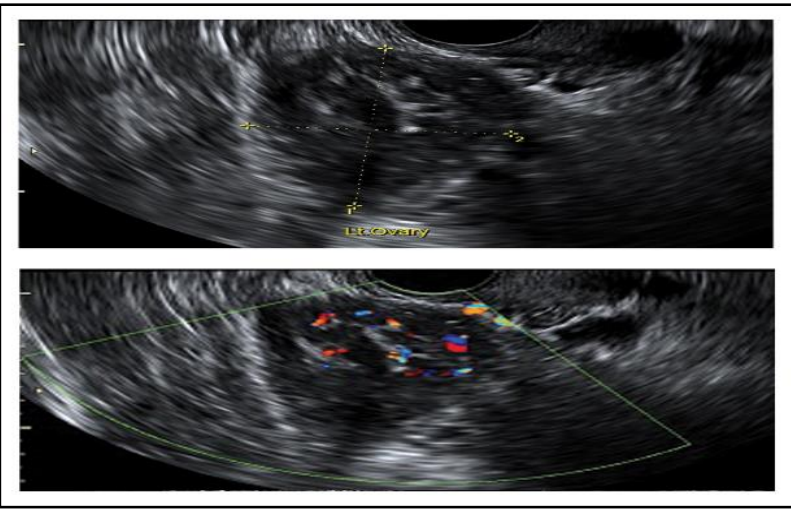

Figure 1: TVS and color doppler of the left ovary.

Serum tumor markers were normal except serum Inhibin B, which was raised to $2249 \mathrm{pg} / \mathrm{ml}$. The patient was advised oncology consultation, but she declined and opted for left adnexectomy. Laparoscopy showed an enlarged 
left ovary with intact surface. Left adnexectomy with staging biopsies and infracolic omentectomy was performed (Figure 2). Uterus and right adnexa appeared normal. Histopathology showed Adult Granulosa Cell tumour with intact ovarian capsule (Figure 3). Left fallopian tube and all biopsies were free of tumour. Her final diagnosis was adult GCT Stage IA. Post-operative period was uneventful. She was followed up at an oncology centre. One month post-surgery, inhibin B level was $44 \mathrm{pg} / \mathrm{ml}$ and had normal menstrual cycle. She wishes to conceive after six months follow-up.

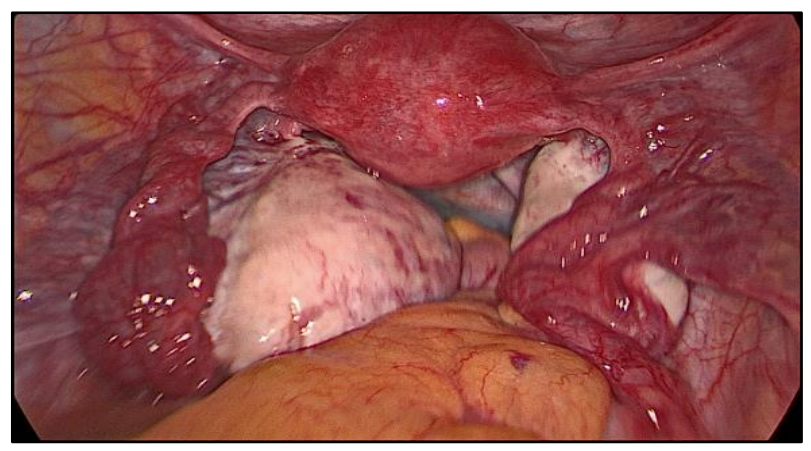

Figure 2: Laparoscopic view of the enlarged left ovary.

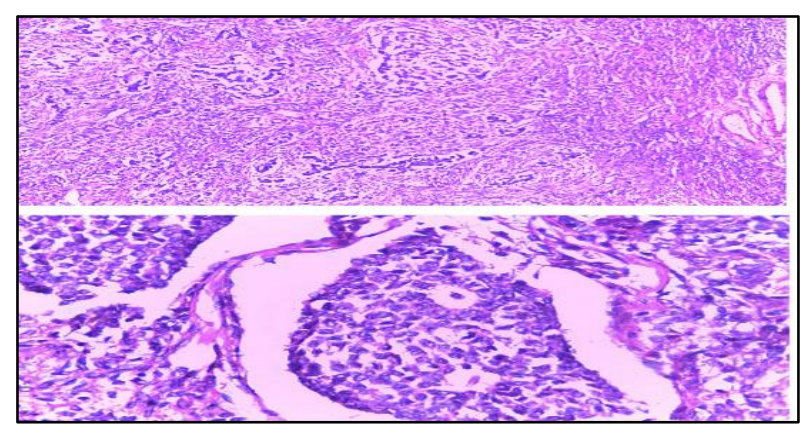

Figure 3: Histopathology showing round or spindleshaped cells with scanty cytoplasm. The nuclei showing central longitudinal grooves (Call - Exner bodies).

\section{DISCUSSION}

Adult granulosa cell tumor (GCT) is a rare ovarian malignancy accounting for $1-2 \%$ of all tumors and $95 \%$ of germ cell tumors originating from sex cord-stromal cells. ${ }^{1-}$ ${ }^{3}$ These have good prognosis in comparison with other epithelial tumors. Juvenile GCT, another clinic-histologic subtype of GCT accounts for 5\%, occurring at a prepubertal age group and have increased risk of recurrence. ${ }^{3}$ Adult GCT has precise clinical, histological and evolutional profile. Adult variant occurs in peri and post-menopausal women with peak incidence at 50-55 years. $^{1,2}$

In our present case, patient presented was in early reproductive age group. The clinical manifestations range from nonspecific to vague symptoms like pain abdomen, abdominal distension and menstrual abnormalities like menorrhagia, intermenstrual, postmenopausal bleeding or amenorrhea. ${ }^{2,3}$ Our patient presented with backache with irregular menstrual cycles. However, in asymptomatic patient, coincidental clinic-radiological examination plays an important role in the diagnosis. Endocrine manifestations are related to estrogen hypersecretion resulting in endometrial hyperplasia, leiomyomas, and irregular menstrual abnormalities. ${ }^{1-3}$ Literature search reveals excessive estrogenic stimulation that leads on to endometrial hyperplasia in $25-50 \%$ and subsequent development of endometrial carcinoma in $5-13 \%$ of cases. ${ }^{2,3}$ Hence, this emphasizes the fact of diligent search of endometrial histology. In the present patient, endometrial histology was not done.

Radiologically both juvenile and adult GCTs present as large mass measuring upto $12 \mathrm{~cm}$ in diameter with solid component / multicystic appearance. ${ }^{2-4}$ Similar radiological findings of solid component were seen in our case. Surgery is the primary treatment modality, which includes complete surgical excision of tumor with unilateral salpingo-oophorectomy in patients desirous of preserving fertility and hysterectomy with bilateral salpingo-oophorectomy, exploration of peritoneal cavity, washings for cytology, multiple peritoneal biopsies and omentectomy in patients who have completed their family. Routine lymphadenectomy is not shown to improve survival. ${ }^{5}$ As bilaterality is encountered in $<2 \%$ patients, wedge biopsy of contralateral ovary is controversial. ${ }^{6}$ Occasionally, patients may need chemo or radiotherapy., ${ }^{2,3}$ In our case, fertility preserving surgery was the treatment of choice since she was married for 2 years and desirous of future pregnancy.

The adult form includes five histologic patterns like micro, macrofollicle, insular, trabecular and spindle/ sarcomatoid. Among these microfollicular pattern with Call-Exner bodies and coffee bean nuclei are the commonest diagnostic features. In the present case, histopathological examination showed round or spindle-shaped cells with scanty cytoplasm. The nuclei showed central longitudinal grooves (Call - Exner bodies). The serum tumor markers raised in GCT are estradiol, inhibin $\mathrm{B}$, anti-mullerian hormone $(\mathrm{AMH})$ and $\mathrm{CA}-125^{2,3}$ In our case, only inhibinB levels were raised. Various prognostic factors in GCT have been reported of which the staging is of paramount importance. Others include intraperitoneal disease, tumor size, patient's age, histologic grade of differentiation, mitotic activity and nuclear atypia. ${ }^{7,8}$ Our case presented with early stage (FIGO-Stage IA).

GCTs have a tendency for late recurrence. In a study by Shanbhag et al, rate of delayed recurrence was found to be $25 \% .{ }^{9}$ The longest reported time to recur was found to be 40 years. $^{10}$ In our case, regular follow-up showed no recurrence or metastasis till date and patient is doing well. She has been advised to try for natural conception and if not successful, can go for assisted reproductive treatment. 


\section{CONCLUSION}

Granulosa cell tumours (GCT) constitute less than 5\% of all ovarian tumors. Although, GCT usually presents in peri/post-menopausal age, it can occur in young reproductive age, as in the present case. The presenting symptoms are usually nonspecific or vague symptoms like abdominal discomfort due to which the diagnosis is delayed. They are more readily cured by surgery alone. The single most important prognostic factor in ovarian GCT seems to be the initial stage of disease. After an apparent clinical cure of the primary tumour, a delayed recurrence of $25 \%$ has been noted. Thus, lifelong follow up with clinical examination, ultrasound and measurement of tumour markers like AMH and inhibin B is recommended. In patients with desire for fertility, a fertility preserving surgery with endometrial biopsy is safe and chemotherapy may be used if indicated without adversely affecting the chance and outcome of future pregnancies. Chemotherapy and/or radiotherapy are considered in patients with advanced stage or with unresectable recurrent disease. 3 Spontaneous conception following removal of the tumour has been reported. There are reports where patients have conceived after ovulation induction and IVF.

Funding: No funding sources Conflict of interest: None declared

Ethical approval: Not required

\section{REFERENCES}

1. Ukah CO, Ikpeze OC, Eleje GU, Eke AC. Adult granulosa cell tumor associated with endometrial carcinoma: A case report. J Med Case Rep. 2011;5:340.

2. Adhikari RC, Jha A, Shayami G. Granulosa cell tumor of the ovary: A clinic-pathological study of six cases. J Pathol Nepal. 2011;1:96-9.

3. Sekkate S, Kairouani M, Serji B, Tazi A, Mrabti H, Boutayeb S, et al. Ovarian granulosa cell tumors: A retrospective study of 27 cases and a review of the literature. World J Surg Oncol. 2013;11:142.

4. Stuart GC, Dawson LM. Update on granulosa cell tumours of the ovary. Curr Opin Obstet Gynecol. 2003;15:33-7.

5. Brown J, Sood AK, Deavers MT, Milojevic L, Gershenson DM. Patterns of metastasis in sex cordstromal tumors of the ovary: Can routine staging lymphadenectomy be omitted? Gynecol Oncol. 2009;113:86-90.

6. National Comprehensive Cancer Network. NCCN Clinical Practice Guidelines in Oncology. 2018 Version 2.2018. Last accessed on March 27, 2018.

7. Lee IH, Choi CH, Hong DG, Song JY, Kim YJ, Kim KT, et al. Clinicopathologic characteristics of granulosa cell tumors of the ovary: A multicenter retrospective study. J Gynecol Oncol. 2011;22:18895.

8. Pectasides D, Papaxoinis G, Fountzilas G, Aravantinos G, Pectasides E, Mouratidou D, et al. Adult granulosa cell tumors of the ovary: A clinicopathological study of 34 patients by the Hellenic Cooperative Oncology Group (HeCOG) Anticancer Res. 2008;28:1421-7.

9. Shanbhag S, Cairns M, Cruickshank M, Dickinson HO, Gokul S, Parkin D. Effectiveness of different treatment modalities for the management of adult onset granulosa cell tumours of the ovary (primary and recurrent). Cochrane Database of Systematic Reviews. 2008;(1):CD006912.

10. Kottarathil VD, Antony MA, Nair IR. Recent Advances in Granulosa Cell Tumor Ovary: A Review. Indian J Surg Oncol. 2013;4:37.

Cite this article as: Paul PG, Thakur S, Annal A, Paul G, Chowdary KA. Incidental diagnosis of granulosa cell tumour in a 25-year-old woman. Int J Reprod Contracept Obstet Gynecol 2021;10:1202-4. 